\title{
Sciaphyllum amoenum (Acanthaceae) is a Peruvian Streblacanthus
}

\author{
Thomas F. Daniel \\ Department of Botany, California Academy of Sciences, Golden Gate Park, San Francisco, \\ California 94118, U.S.A.
}

\begin{abstract}
Sciaphyllum amoenum has been known solely from cultivated plants of unknown origin. This species exhibits all of the diagnostic characteristics of Streblacanthus but is not conspecific with any previously described species of that genus. The cultivated specimens, including the type, of $S$. amoenum correspond to an undescribed series of collections from Peru. Thus the species is transferred to Streblacanthus, and its place of origin can be established. Streblacanthus amoenus is compared with the other species of this genus of American plants. Streblacanthus boliviensis is considered to be a synonym of $S$. dubiosus.
\end{abstract}

Bremekamp (1940) described a plant known to him only from cultivated material as a new genus and species, Sciaphyllum amoenum Bremekamp. Plants were reported to have been cultivated in Europe (the Netherlands and England) and Asia (Java), but their origin was not known. Bremekamp (1940) concluded that $S$. amoenum would be included in his Odontonemeae, and he discussed its probable relatives in that tribe. He noted that $S$. amoenum had pollen similar to Streblacanthus Kuntze, but he did not pursue other similarities to or differences from this genus. Bremekamp's description and figure both suggested to me a likely relationship with Streblacanthus, and examination of type material confirms that Sciaphyllum amoen$u m$ belongs in that genus.

Streblacanthus is a small American genus of Odontonemeae characterized by corollas with a long, narrow tube and a bilabiate limb; an androecium of two stamens and no staminodes; tricolporate pollen with six pseudocolpi; and capsules with flattened, subcircular heads. Eight names have been utilized in the genus; however, many of these have been synonymized or shown to refer to species in other genera. For example, Daniel (1990) transferred Streblacanthus parviflorus Leonard to Schaueria Nees; Daniel (1993) included Streblacanthus chirripensis Lindau in the synonymy of Justicia chamaeranthemodes (Kuntze) T. F. Daniel; and Durkee (1986) included both Streblacanthus macrophyllus Lindau and Streblacanthus longiflorus
Cufodontis within Streblacanthus monospermus Kuntze.

Sciaphyllum amoenum has all of the diagnostic characteristics of Streblacanthus but is not conspecific with any of the remaining species in that genus. However, there are numerous unidentified Peruvian collections of Streblacanthus at US that correspond to Bremekamp's (1940) description and illustration, the type specimen at $\mathrm{U}$, and other specimens from cultivated plants. Sciaphyllum amoenum is therefore transferred to Streblacanthus, and the provenance of this cultivated plant can be established as Peru. The unispecific genus Sciaphyllum Bremekamp becomes a synonym of Streblacanthus. A comprehensive description of the species is provided based on cultivated and field-collected specimens.

Streblacanthus Kuntze, Rev. Gen. Pl. 1: 497. 1891. TYPE SPECIES: Streblacanthus monospermus Kuntze.

Sciaphyllum Bremekamp, Recueil Trav. Bot. Néerl. 37: 298. 1940. Syn. nov. TYPE SPECIES: Sciaphyllum amoenum Bremekamp.

Streblacanthus amoenus (Bremekamp) T. F. Daniel, comb. nov. Basionym: Sciaphyllum amoenum Bremekamp, Recueil Trav. Bot. Néerl. 37: 298. 1940. TYPE: Indonesia. West Java: Buitenzorg (= Bogor) suburb of Kotta Paris, 4 July 1922, R. C. Bakhuizen van den Brink, Jr. 1402 (holotype, U; see discussion).

Erect perennial herb or shrub to $2.5 \mathrm{~m}$ tall; young stems subterete to subquadrate, evenly pubescent with straight eglandular trichomes and inconspicuous sessile or stipitate glands up to 0.05 $(-0.1) \mathrm{mm}$ long. Leaves petiolate; petioles to 135 $\mathrm{mm}$ long; blades deltate to broadly ovate to ovateelliptic, 65-270 mm long, 52-180 mm wide, 1.11.7 times longer than wide, acute to subacuminate at apex, rounded to truncate to subcordate at base, surfaces green adaxially, purplish abaxially, pubescent (especially along major veins) with cauline type trichomes; a pair of reduced, sessile leaves often subtends inflorescence. Inflorescence of ax- 


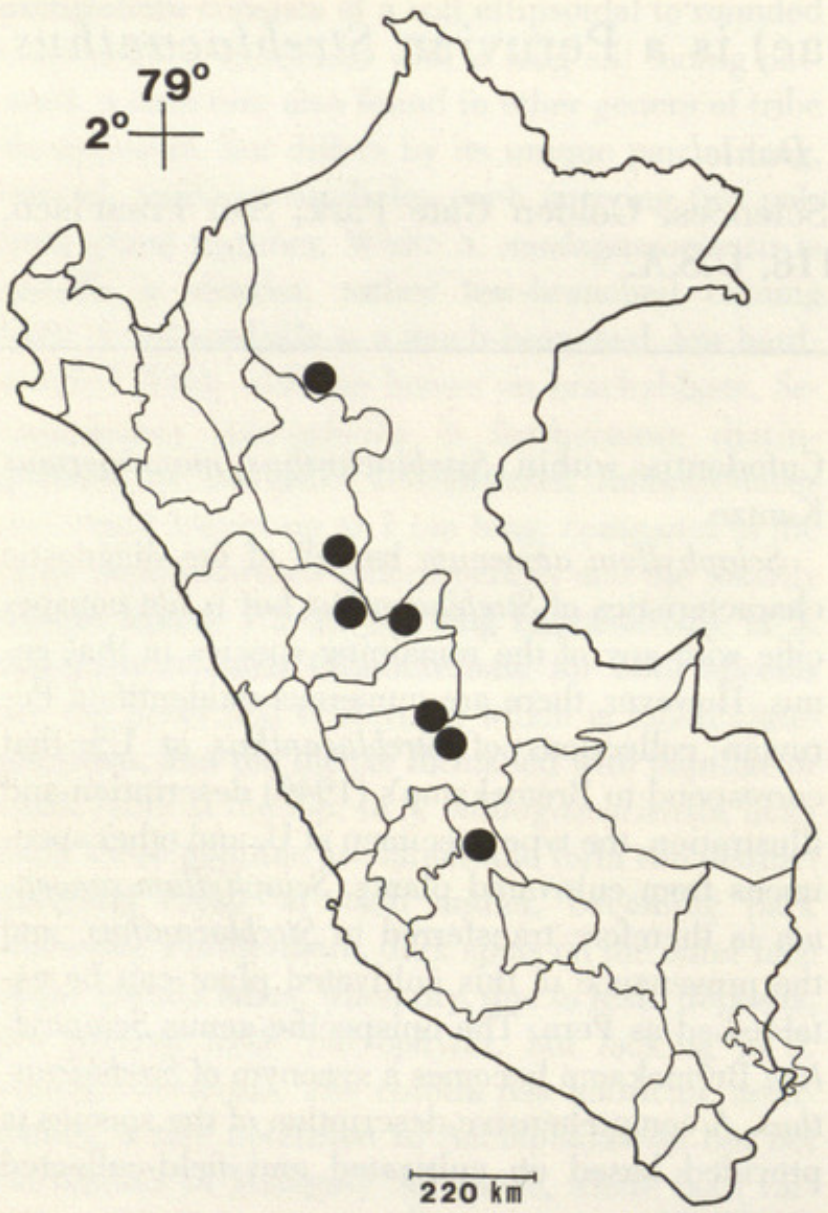

Figure 1. Map of Peru showing the natural distribution of Streblacanthus amoenus.

illary and terminal pedunculate spicate thyrses to $4.5 \mathrm{dm}$ long (including peduncle and excluding flowers), these sometimes branched proximally; peduncles (to first branch or dichasium) to $110 \mathrm{~mm}$ long, rachis pubescent with straight to flexuose eglandular (and \pm inconspicuous glandular) trichomes to $0.5 \mathrm{~mm}$ long (see discussion); dichasia opposite (to subopposite to alternate) at nodes, sessile; flowers 1-7 per dichasium, subsessile or borne on pedicels to $3.5 \mathrm{~mm}$ long. Bracts sessile, triangular to ovate to lanceolate, $1.5-5 \mathrm{~mm}$ long, $0.7-$ $2.5 \mathrm{~mm}$ wide, pubescent like rachis. Bractlets and secondary bractlets triangular to ovate to lanceolate, 1-3 mm long, 0.5-1 mm wide, pubescent like rachis. Calyx 5-lobed, 5-8.5 mm long; lobes lancesubulate, $4.5-8 \mathrm{~mm}$ long, externally pubescent with glandular (sometimes inconspicuous or represented by sessile glands only) and eglandular trichomes to $0.2 \mathrm{~mm}$ long. Corolla purplish or pinkish, 24-36 (-40) $\mathrm{mm}$ long, externally pubescent with flexuose eglandular trichomes to $0.5(-1) \mathrm{mm}$ long; tube gradually ampliate distally from near midpoint or more abruptly ampliate distally into a throat (4-) 10-16 mm long, 2.5-5 mm diam.; upper lip \pm triangular, 4-8 $\mathrm{mm}$ long, apically emarginate; lower lip 4-10 $\mathrm{mm}$ long with elliptic (to subcircular) lobes 4-8 mm long, 2.5-6 mm wide. Stamens exserted from corolla tube; thecae parallel, $2-2.2 \mathrm{~mm}$ long. Style 19-35 mm long, glabrous (or sparsely pubescent proximally); stigma subcapitate, $0.2 \mathrm{~mm}$ long. Capsule 11.5-17 mm long, pubescent with straight to flexuose eglandular trichomes $0.05-0.5$ $\mathrm{mm}$ long. Seeds 4, flat, subcordate, 4-4.7 mm long, $3.5-4.5 \mathrm{~mm}$ wide, surface and margin papillose.

Phenology. Flowering: May-December; fruiting: June-December.

Distribution. Native to Peru (Fig. 1; Ayacucho, Huánuco, Junín, Loreto, and San Martín); plants occur in tropical moist forests at elevations from 250 to $800 \mathrm{~m}$. Cultivated in Europe, Asia, North America, South America, and the West Indies.

Additional specimens examined. NETHERLANDS. Utrecht: Baarn, Cantonspark 3404 (U). U.S.A. California: San Francisco Co., Strybing Arboretum, Golden Gate Park, San Francisco, E. McClintock s.n. (CAS). Florida: Hillsborough Co., U.S.F. Botanical Garden, D. Burch 4154 (CAS, MO); Lee Co., Alva, cultivated at River Haven Nursery from seed from Andromeda Gardens, Barbados, T. Plowman 13284 (US). PERU. Ayacucho: Estrella, between Huanta and Río Apurimac, E. Killip \& A. Smith 23089 (US). Huánuco: Puente Tulumayo entre T. M. y Divisoria, R. Ferreyra 4331 (US); Pachitea, Sungaro, W of Puerta Inca, along hwy. $10 \mathrm{~km} \mathrm{~S}$ of Sungaro River crossing, $9^{\circ} 22^{\prime} \mathrm{S}, 75^{\circ} 00^{\prime} \mathrm{W}$, R. Foster 8787 (US); prov. Leoncio Prado, distr. Rupa Rupa, Cueva de las Lechuzas, Tingo María, J. Schunke V. 3100 (US); prov. Leoncio Prado, distr. Rupa Rupa, Calpar Bella, cueva de los Hauriños, J. Schunke V. 9478 (US); prov. Leoncio Prado, distr. Rupa Rupa, along Río Monzon, trail to Cueva de las Lechuzas, D. Wasshausen \& O. Tovar 1256 (US). Junín: prov. Chanchamayo, San Ramon, cultivated, M. Antonieta $V . \& R$. Fernández 89 (US); between Azupizu and Santa Rosa, Pichis Trail, E. Killip \& A. Smith 26135 (US); Río Negro, F. Woytkowski 5798 (US). Loreto: Balsapuerto (lower Río Huallaga basin), E. Killip \& A. Smith 28694 (US). San Martín: prov. Mariscal Cáceres, distr. Tocache Nuevo, Quebrada de Huaquisha (márgen derecha del Río Huallaga), J. Schunke V. 8649 (US); prov. Mariscal Cáceres, distr. Tocache Nuevo, Quebrada Cachiyacu de Huaquisha, J. Schunke V. 12487 (US).

In the protologue, Bremekamp (1940) did not specifically designate a type of Sciaphyllum amoen$u m$. The only herbarium specimen to which he directly referred, that cited as the holotype above, bears his determination in ink to which was added "Typus" in pencil. Because this specimen lacks capsules and seeds whereas Bremekamp's (1940) description and illustration included these, he undoubtedly utilized materials cultivated at the University Botanical Garden in Utrecht, to which he referred, in devising his protologue. In fact, it is clear from the protologue that such material formed the basis for most of the descriptive data. The only 
herbarium specimen of $S$. amoenum at $\mathrm{U}$ based on a cultivated plant (that cited above from Baarn) was not collected until 1951. Collector's information on the type specimen from the island of Java indicates that it was probably cultivated there. The circumstances surrounding the introduction of this species into cultivation around the world remain unknown.

The species shows considerable variation in corolla form (especially length of the throat, which, however, is always longer than in S. dubiosus (Lindau) V. M. Baum) and rachis pubescence. Rachis pubescence varies from glandular puberulent with mostly sessile glandular and eglandular trichomes up to $0.05 \mathrm{~mm}$ long (e.g., Killip \& Smith 23089) to glandular puberulent and with a dense and even overstory of straight to flexuose eglandular trichomes 0.2-0.4 mm long (e.g., Killip \& Smith 28694) to glandular puberulent and with a dense and even overstory of straight glandular trichomes 0.1-0.2 mm long (e.g., Antonieta V. \& Fernández 89 ).

Streblacanthus amoenus can be distinguished from $S$. monospermus of Costa Rica and Panama by its evenly pubescent young stems with trichomes to $0.1 \mathrm{~mm}$ long (vs. bifariously pubescent with trichomes greater than $0.3 \mathrm{~mm}$ long), rounded to truncate to subcordate leaf bases (vs. acute to attenuate bases), bracts and bractlets shorter than the calyx (vs. longer than the calyx), and 5-lobed calyces (vs. 4-lobed calyces). Streblacanthus amoenus differs from $S$. cordatus Lindau (including $S$. cordifolius T. F. Daniel) of Costa Rica, Panama, Colombia, and Ecuador by its shorter calyces (5-8.5 mm long vs. $10-25 \mathrm{~mm}$ long) and larger corolla throats (4-16 $\mathrm{mm}$ long and $2.5-5 \mathrm{~mm}$ diam. vs. $1.5-2.5 \mathrm{~mm}$ long and 2-2.5 mm diam.). Streblacanthus amoenus most closely resembles the southern South American species $S$. dubiosus. These species can be distinguished by the following couplet:

Young stems inconspicuously puberulent with straight eglandular trichomes and sessile glands to $0.05(-0.1) \mathrm{mm}$ long; corolla tube ampliate for (4-) $10-$ $16 \mathrm{~mm}$ forming a gradually funnelform throat, the throat $2.5-5 \mathrm{~mm}$ diam.; trichomes on capsule to 0.5

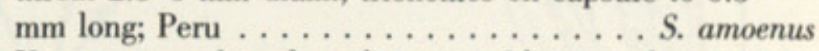
Young stems densely pubescent with an understory of straight eglandular trichomes $0.1-0.2 \mathrm{~mm}$ long and an overstory of flexuose to antrorse eglandular trichomes to $1 \mathrm{~mm}$ long; corolla tube abruptly ampliate near apex for 1-2 mm forming a short throat, the throat 2-2.5 mm diam.; trichomes on capsule 0.2$1.3 \mathrm{~mm}$ long (at least some always $>0.5 \mathrm{~mm}$ long); Peru, Bolivia, Paraguay, Argentina, and Brazil . . . ..................... S. dubiosus

Based on my preliminary studies of a large series of specimens and type photographs, Streblacanthus boliviensis Lindau is here included in $S$. dubiosus. The resulting species forms a morphologically variable complex with both glandular and eglandular individuals. This species and the recently expanded and variable Central American $S$. monospermus (Durkee, 1986) are deserving of further studies.

Acknowledgments. I thank the curators at CAS, MO, U, and US for loans or permitting access to their collections. Herbarium travel expenses were funded by the In-House Research Fund of the California Academy of Sciences.

\section{Literature Cited}

Bremekamp, C. E. B. 1940. Sciaphyllum, genus novum Acanthacearum. Recueil Trav. Bot. Néerl. 37: 293-300. Daniel, T. F. 1990. New and reconsidered Mexican Acanthaceae. IV. Proc. Calif. Acad. Sci. 46: 279-287.

1993. Taxonomic and geographic notes on Central American Acanthaceae. Proc. Calif. Acad. Sci. 48: 119-130.

Durkee, L. H. 1986. Acanthaceae. Pp. 1-87 in W. Burger (editor), Flora Costaricensis. Fieldiana: Bot. 18. Field Museum of Natural History, Chicago. 


\section{$2 \mathrm{BHL}$ Biodiversity Heritage Library}

Daniel, Thomas Franklin. 1996. "Sciaphyllum amoenum (Acanthaceae) is a Peruvian Streblacanthus." Novon a journal of botanical nomenclature from the Missouri Botanical Garden 6, 147-149. https://doi.org/10.2307/3391911.

View This Item Online: https://www.biodiversitylibrary.org/item/14666

DOI: https://doi.org/10.2307/3391911

Permalink: https://www.biodiversitylibrary.org/partpdf/28336

\section{Holding Institution}

Missouri Botanical Garden, Peter H. Raven Library

\section{Sponsored by}

Missouri Botanical Garden

\section{Copyright \& Reuse}

Copyright Status: In copyright. Digitized with the permission of the rights holder.

License: http://creativecommons.org/licenses/by-nc-sa/3.0/

Rights: https://biodiversitylibrary.org/permissions

This document was created from content at the Biodiversity Heritage Library, the world's largest open access digital library for biodiversity literature and archives. Visit BHL at https://www.biodiversitylibrary.org. 